\title{
The Impact of Taxation on the Development of Geothermal Resources
}

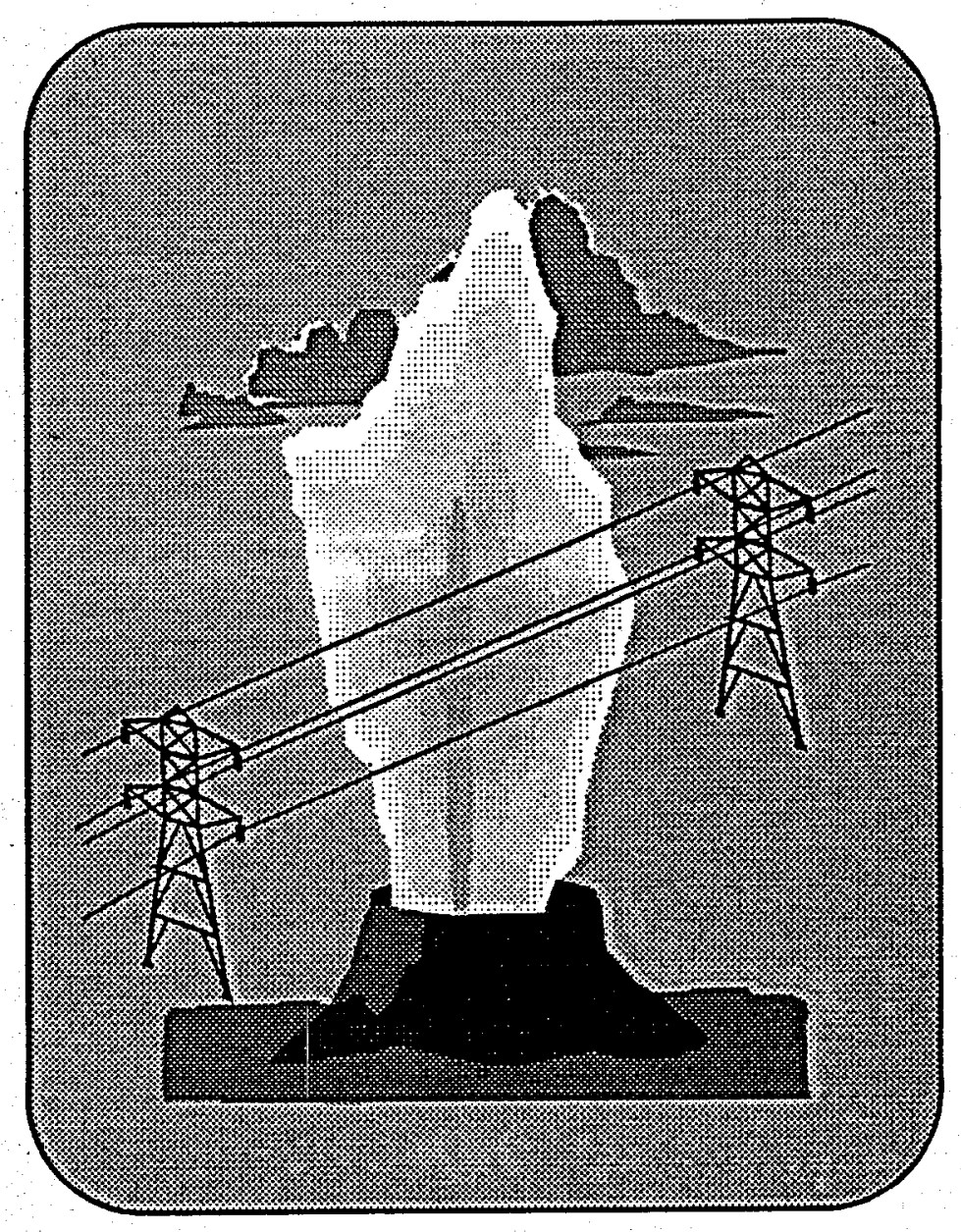

By:

BNF Technologies Inc. Alexandria, VA 22302

For:

U.S. Department of Energy Geothermal Division Conservation and Renewable Energy 


\section{DISCLAIMER}

This report was prepared as an account of work sponsored by an agency of the United States Government. Neither the United States Government nor any agency Thereof, nor any of their employees, makes any warranty, express or implied, or assumes any legal liability or responsibility for the accuracy, completeness, or usefulness of any information, apparatus, product, or process disclosed, or represents that its use would not infringe privately owned rights. Reference herein to any specific commercial product, process, or service by trade name, trademark, manufacturer, or otherwise does not necessarily constitute or imply its endorsement, recommendation, or favoring by the United States Government or any agency thereof. The views and opinions of authors expressed herein do not necessarily state or reflect those of the United States Government or any agency thereof. 


\section{DISCLAIMER}

Portions of this document may be illegible in electronic image products. Images are produced from the best available original document. 


\title{
GEOTHERMAL ENERGY ANALYSIS PROGRAM
}

\section{The Impact of Taxation on the Development of Geothermal Resources}

\author{
September 1992
}

prepared for the:

U.S. Department of Energy

Geothermal Technology Division

prepared by:

Michael Gaffen and James Baker BNF Technologies Inc. 4401 Ford Avenue, Suite 310 Alexandria, VA 22302 
MMPACT OF TAXATIONON THE DEVELOPMENT OF GEOTHERMALRESOURCES

TABLE OF CONTENTS

TITLE

PAGE NO

EXECUTIVE SUMMARY $\ldots \ldots \ldots \ldots \ldots \ldots \ldots \ldots \ldots \ldots \ldots \ldots \ldots \ldots \ldots \ldots \ldots \ldots \ldots \ldots$

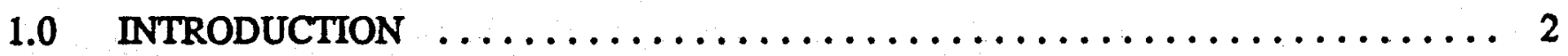

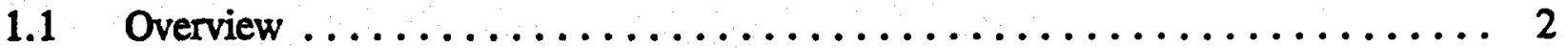

1.2 Federal Taxation of Geothermal Resources $\ldots \ldots \ldots \ldots \ldots \ldots \ldots \ldots . \ldots 4$

1.3 State Tax and Financial Incentives $\ldots \ldots \ldots \ldots \ldots \ldots \ldots \ldots \ldots \ldots$

1.4 Foreign Financial Incentives $\ldots \ldots \ldots \ldots \ldots \ldots \ldots \ldots \ldots \ldots \ldots$

2.0 FEDERAL TAXES ON GEOTHERMAL RESOURCES $\ldots \ldots \ldots \ldots \ldots \ldots \ldots 5$

2.1 Federal Taxes on Energy Resources $\ldots \ldots \ldots \ldots \ldots \ldots \ldots \ldots \ldots \ldots$

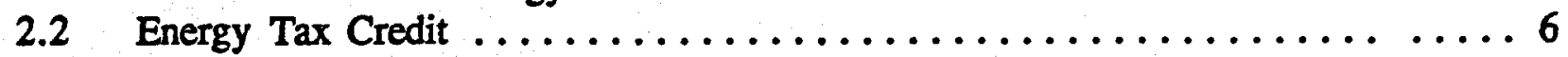

2.3 Investment Tax Credit $\ldots \ldots \ldots \ldots \ldots \ldots \ldots \ldots \ldots \ldots \ldots \ldots \ldots, 8$

2.4 Depletion Allowance $\ldots \ldots \ldots \ldots \ldots \ldots \ldots \ldots \ldots \ldots \ldots \ldots \ldots \ldots \ldots$

2.5 Depreciation: MACRS vs. ACRS $\ldots \ldots \ldots \ldots \ldots \ldots \ldots \ldots \ldots \ldots \ldots$

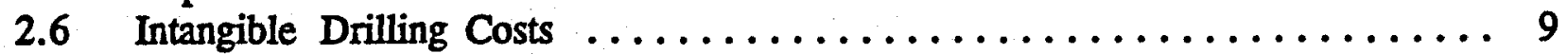

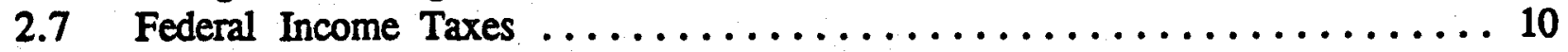

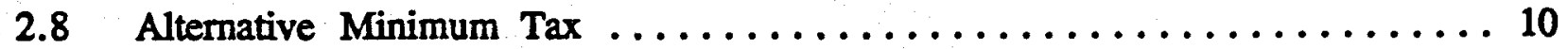

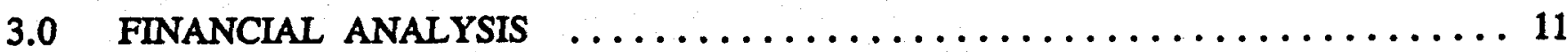

4.0 INDUSTRY REVIEW $\ldots \ldots \ldots \ldots \ldots \ldots \ldots \ldots \ldots \ldots \ldots \ldots \ldots \ldots \ldots \ldots \ldots \ldots$

5.0 STATE FINANCIAL INCENTTVES $\ldots \ldots \ldots \ldots \ldots \ldots \ldots \ldots \ldots \ldots \ldots \ldots \ldots \ldots \ldots \ldots$

6.0 INTERNATIONAL FINANCIAL INCENTIVES $\ldots \ldots \ldots \ldots \ldots \ldots \ldots \ldots \ldots$

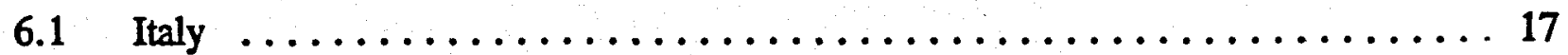

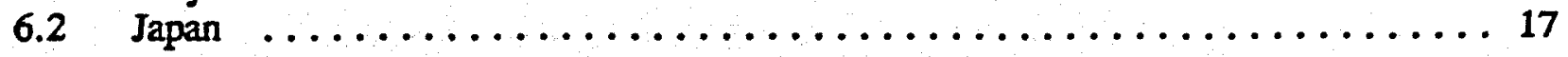

APPENDIX A-DISCUSSION OF THE BASECASE ANALYSIS $\ldots \ldots \ldots \ldots \ldots \ldots 18$

APPENDIX B - GLOSSARY OF ECONOMIC TERMS $\ldots \ldots \ldots \ldots \ldots \ldots \ldots \ldots$

LIST OF FIGURES

Figure 1: New Geothermal Power Capacity In The U.S. $\ldots \ldots \ldots \ldots \ldots \ldots \ldots \ldots 7$

Fiqure 2: Typical Geothermal Binary Plant (Sensitivity Analysis) $\ldots \ldots \ldots \ldots \ldots \ldots \ldots 12$

Figure A-1: Typical Geothermal Binary Plant (Revenues vs. Expenses) $\ldots \ldots \ldots \ldots \ldots 22$

Figure A-2: Typical Geothermal Binary Plant (Cumulative Revenues vs. Expenses) $\ldots \ldots \ldots 23$

Figure A-3: Typical Geothermal Binary Plant (Sensitivity Analysis) $\ldots \ldots \ldots \ldots \ldots \ldots 24$

Figure A-4: IRR for Geothermal Binary Plant $(80 \%$ Leverage) $\ldots \ldots \ldots \ldots \ldots \ldots \ldots \ldots$

Figure A-5: IRR for Geothermal Binary Plant $(85 \%$ Leverage) $\ldots \ldots \ldots \ldots \ldots \ldots \ldots$ 


\section{EXECUTIVE SUMMARY}

Tax legislation has been used by federal and state governments to stimulate commercialization of new energy technologies. The system of renewable energy tax credits was initiated in 1978 to accelerate commercial investment in renewable technology including geothermal projects. Since 1985 , these tax credits have been renewed on a periodic basis. The availability of tax incentives for new geothermal facilities was an important catalyst for the initial commercialization of this developing technology during the 1980s. The geothermal industry is now more mature, with a history of successful projects, and financing requirements for all renewable energy facilities have changed substantially. This report reviews past and current tax mechanisms for renewable energy, analyzes them specifically for the development and operations of geothermal energy facilities, and discusses the implications of an extension of the U.S. Federal Energy Tax Credit (ETC) on future geothermal investments.

The results of a financial analysis of a representative $50 \mathrm{MW}$ binary geothermal plant indicate that geothermal projects, since they are highly capital-intensive, are financially sensitive to tax credits and exclusions, turnkey construction costs, and utility power sales agreement rates. An informal survey has provided insights into the views and concerns of the geothermal-related industry toward pending legislation.

Changes and uncertainty in economic, financial, legislative, environmental, and institutional factors have increased financial risk over the past several years, causing potential investors to require that a project be financially viable, i.e., demonstrate a significant near-term positive cash flow, independent of any tax or other credit incentives. In addition, the possibility of tax credits evaporating due to legislative changes, after an energy facility becomes operational, has inhibited conventional financing. This report demonstrates that an effective energy tax credit extension of over two years, or a permanent credit, rather than the current six months to a year, is required to allow sufficient time for the planning, design, and construction and operation of new geothermal plants. 


\subsection{INTRODUCTION}

This report reviews and analyzes the role of tax mechanisms on the development and operation of geothermal energy facilities. The objective is to analyze the influence of various tax policies on the financial viability of geothermal power plants. Geothermal facilities are relatively capital intensive, compared to conventional fossil fuel plants, producing potentially inequitable tax burdens on geothermal producers and, ultimately, on consumers. This analysis was undertaken to assist the Geothermal Division of the Department of Energy: Office of Renewable Energy

i. Conversion, in reviewing the impact of existing and proposed tax legislation on geothermal projects.

\subsection{Overview}

Tax legislation has been used by federal and state governments to stimulate energy project developments necessary to encourage commercialization of new energy technologies. A system of renewable energy tax credits was initiated in 1978 to accelerate commercial investment in renewable technology, including geothermal resources. The renewable energy tax credits were authorized by legislation that expired in 1985, although some of the credits were retained. Through 1991 , these credits were renewed on an annual basis at lower rates, at federal and state levels. The federal energy tax credit expired on June 30,1992, although there are proposals to continue the extension beyond that date.

This analysis explores (1) the impact of tax incentives on the development of geothermal facilities constructed or proposed since 1980 , and (2) the implications of pending legisiation to terminate, extend, change, or phase out the renewable tax credit. Also included is an informal survey of current industry views on tax incentives for geothermal facilities. A standard pro forma analysis of typical revenue and expense flows was developed to analyze the sensitivity of a new geothermal project to the primary financial factors, including tax incentives. The details are included in Appendix A. This review includes the existing tax incentives relating to geothermal operations at the state level in California and information on the approach utilized by some foreign governments.

A glossary of economic and financial terms is presented in Appendix B.

It appears that the availability of tax incentives for new geothermal facilities was an important catalyst for initial commercialization of this developing technology during the 1980 s. The geothermal industry is now more mature, with a history of successful projects, and financing requirements for all renewable energy facilities have changed substantially. To obtain conventional 
financing for new geothermal venture projects in the current financial arena, adequate cash flows to support the project retums without consideration of tax incentives must be demonstrated. Financial support from tax incentives for geothermal facilities may be considered in the final financial evaluation. However, the financial industry's perception of uncertainty and resultant risk inherent in federal legislation has diminished the initial importance of tax credits for new project financing. Credits make viable projects stronger, resulting in lower financing costs. Geothermal projects are site specific and each new project is subject to a unique financial strategy, due to a wide range of technical and company-related considerations.

This review addresses two related questions:

Q1) Was the tax credit a consideration in initiating new geothermal developments in the 1980s? and,

Q2) Are tax credits currently important incentives for initiating new geothermal developments?

Preliminary indications are that:

AI) The availability of tax credits was a catalyst for initiating new geothermal developments, particularly in the 1983-88 period; and

A2) The continued access to tax and other credit incentives currently may not be as important as in the past, since economic, financial, environmental and institutional factors have changed over the past five years. The geothermal power industry is now more mature, and innovative approaches are not as important as the requirement for financially viable projects.

However, long term credits are still used to help to reduce the very high capital cost of geothermal power projects so they may better compete with lower cost fuels such as gas and coal.

\subsection{Federal Taxation of Geothermal Resources}

Tax policy may be designed to provide incentives or adjustments to enhance the financial operations of a business. To stimulate development of geothermal energy, both federal and state 
laws offer specific incentives for investment in geothermal projects. The geothermal industry has the potential for continued use of tax credits on both the supply and demand sides of geothermal development.

To stimulate energy supply, drilling and development of geothermal fields located on federal lands have utilized special federal financial adjustments. To help stimulate demand for geothermal power by regulated electric utilities, the Public Utilities Regulatory Policies Act [PURPA] of 1978 requires electric utilities to purchase power from "qualifying facilities, "including geothermal plants, at a price equal to the "avoided cost" of an alternative supply for the utility. State utility commissions are required by PURPA to define the "avoided cost" rate. Additionally, the federal energy tax credit has been the catalyst for stimulating investments in geothermal facilities and, in many cases, has provided sufficient margins for the financial viability of several, otherwise uneconomical geothermal power plants.

\subsection{State Tax and Financial Incentives}

Financial incentives for renewable energy projects have been developed at the state level, particularly in Califomia where the California Energy Commission (CEC) has established an innovative grant and loan program, in addition to state tax incentives consisting of energy tax credits, accelerated depreciation, and property tax exclusions.

\subsection{Foreign Financial Incentives}

The International Energy Agency (IEA) has been a forum for discussion on financial initiatives for renewable energy. Foreign taxes on energy are designed to support several policy initiatives, including: raise revenue, reduce or increase supply of one source or fuel, and internalize external costs particularly environmental concerns. Taxes have been major aspects of all energy policies in several geothermal resource countries, such as Japan, Iceland, Greece, and New Zealand.

Concerns over the long-term environmental consequences of fossil fuel use in the industrial countries have prompted broad interest in a fossil fuel tax. Most member countries of the IEA have considered energy taxes specifically designed to reduce the use of particular fossil fuels, particularly coal, and economic incentives to reduce $\mathrm{CO}_{2}$ or $\mathrm{SO}_{2}$ emissions. This potential negative tax on fossil fuels could also be an effective positive financial incentive for the development of new geothermal facilities, or other non-fossil energy sources. 


\subsection{FEDERAL TAXES ON GEOTHERMALRESOURCES}

\subsection{Federal Taxes on Energy Resources}

U.S. tax laws and regulations are perhaps the most arcane, complex, and adjudicated aspects of legislation. This section of the analysis reviews the provisions of the tax laws applicable to the development of geothermal resources and the potential impact on new geothermal projects.

A distinction must be made between tax credits used to subsidize production from specific energy resources, and those used to stimulate commercial development of a new technology, such as geothermal resources. The tax credits applicable to geothermal facilities were enacted as part of the Energy Tax Act of 1978. These credits were also applicable to a number of other renewable energy technologies, including solar and wind. Under those rules, if a project became operational at any time during the year, it was eligible for tax credits for the entire year. Therefore, numerous facilities accelerated construction to commence operation in the last month of each year. The original five-year qualification period for new geothermal facility development expired in 1985 and was replaced by an annual deadline. The tax credits were last extended for a six month period, and expired on June 30,1992. This placed a stringent requirement for the actual placement in service and operation of the facility within the deadline period in order to quality for the tax credit. Therefore, accelerated construction schedules were focused on completion and generation of power by the end of that year. A delay in initial commercial operations of the facility could result in substantial financial losses due to the anticipated expiration of the tax credits, since the developer had no guarantee the credit would be continued. This perceived risk of not qualifying for the tax credits due to construction delays, or of the tax credits evaporating due to legislation changes after a plant becomes operational, has inhibited conventional financing.

Figure 1 indicates the cumulative federal energy and investment tax credit available for the period 1981 to 1990 , and the level of new geothermal facilities capacity initiated in those years. The level of new geothermal power capacity does not appear to be directly related to the changing tax credits even considering a two to three year lag due to development and construction time. Among the many factors contributing to the opening of new facilities were: local and regional power demand, alternative supply availability, new plant construction time, prices of competing fuels, and the state regulatory environment. 
The level of potential tax benefits available for new geothermal facilities may have inflated the apparent growth of the industry in the mid-1980's. For some projects, investors were assured of positive returns through implied tax benefits rather than on the viability of the geothermal operation. Federal tax credits have included energy investment and accelerated depreciation credits.

The federal energy tax credit and the investment tax credit require that qualifying facilities and equipment be placed in service during the tax year, and be fully operational during the five year recapture period. The California solar energy tax credit was more generous and included no restrictive recapture provision, once the facility was operational. This may have attracted entrepreneurs who were motivated by the immediate profits available from the initial development, instead of the long-term operating revenues, since it had no "economic purpose test".

\subsection{Energy Tax Credit}

The Energy Tax Credit (ETC) ${ }^{1}$ was the most significant Federal tax advantage provided for the geothermal industry. The credit permitted 10 percent of capital investment for tangible, depreciable, new geothermal property to be written off. Tangible field property, including well casings and associated systems, also were eligible, although power transmission and connection systems were not. The ETC was initially enacted in 1981, as part of the Economic Recovery Tax Act, at a 15 percent rate, reduced to 12 percent in 1986 and continued since 1987, by an annual extension at a 10 percent rate.

\footnotetext{
1991 Master Tax Guide, $\$ 1229$ Commerce clearinghouse
} 


\section{NEW GEOTHERMAL POWER CAPACITY IN THE U.S.: 1981 - 1990}

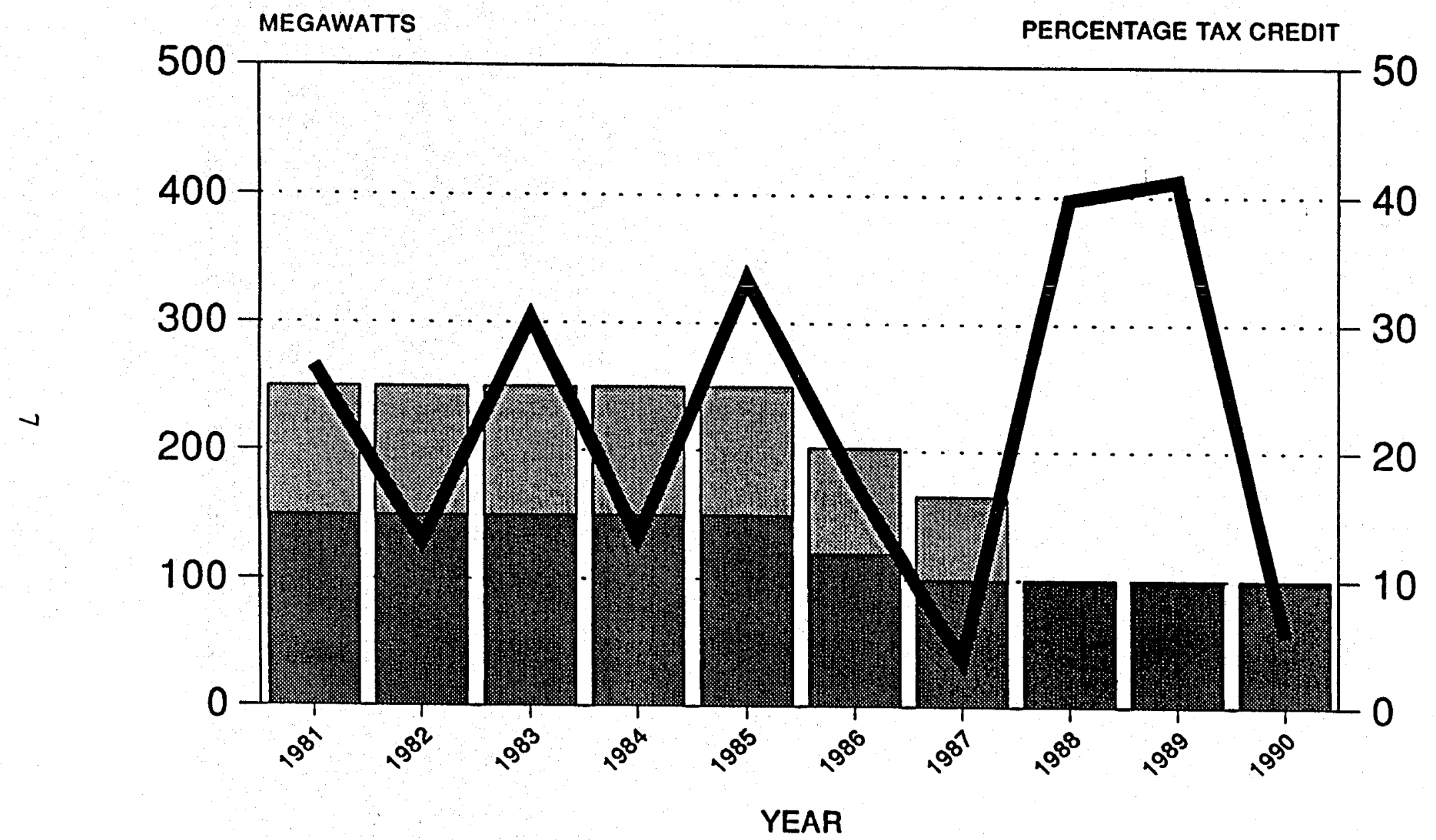

MW Installed TFED Energy Tax Credit 0 FED Investment Tax Credit (Plotted on Y2 Axis)

Figure 1: New Geothermal Power Capacity In The U.S. 
The limited life of the last six month ETC extension, and the uncertainty of future extensions, considering the time required for the completion of a typical geothermal project development period, decrease the value of this tax incentive for new geothermal operations. A typical project can take a minimum of one year to design and develop to the point of construction, and another year to construct and reach commercial operation.

There are special rules for recapture of the energy tax credit and the investment tax credit for property defined as five, ten or fifteen-year property. The federal ETC used ITC [Investment Tax Credit] regulations. The only requirement was that the equipment be placed in service during the tax year and continue in operation during the five year recapture period. The recapture period is to ensure that if the project is permanently removed from service before the end of the five year period, a portion of the credit, equal to 20 percent per year of the credit, would be repaid. The project also had to have "economic substance".

\subsection{Investment Tax Credit}

Developers engaged in the business or holding property for the production of income from geothermal resources are allowed an investment tax credit (TTC) ${ }^{2}$ up to ten percent, based on the percentages of qualified investment placed in service in the tax year. The tax credit was available only for geothermal property that was new and had a useful life of three or more years. The investment tax credit (ITC) was implemented in 1962 and provided an incentive for firms to purchase new machinery and equipment to promote economic growth. The assumption was that investments in infrastructure, including machinery and equipment, would contribute to economic growth more efficiently than other forms of capital investment. The ITC, until its elimination in 1987, was important to geothermal developments, since most projects received the credit under transition rules until 1990.

\subsection{Depletion Allowance}

A deduction reflecting depletion ${ }^{3}$ is allowed in determining the income from geothermal resources. A geothermal deposit is a reservoir of natural heat stored in rocks or in a watery liquid

21991 US Master Tax Guide $\$ 1361$

Commerce clearinghouse

1991 us Master Tax Guide, \$1289, \$1294 Comerce Clearinghouse 
or vapor. It is not considered a gas well. Gross income from the property does not included lease bonuses, advanced royalties, or other amounts payable without regard to production from the property. Geothermal resources qualify for a percentage depletion allowance at the rate of 15 percent of the value of the resources sold. This is similar to the depletion allowance rate for oil and gas producers, although these energy fuels have additional restrictions. The depletion or geothermal development equipment was left without restrictions in order to encourage this underdeveloped resource. The developer may choose the cost depletion method instead of the percentage depletion; he may use cost depletion to reduce the property basis, switching to percentage depletion based on gross income after the cost basis is reduced to zero. The depletion allowance had a greater impact on projects in the early 1980's then currently.

\subsection{Depreciation: MACRS vs. ACRS}

In the case of business property related to the development or production of geothermal reserves, allowances for the costs of geothermal systems, can be depreciated using the MACRS ${ }^{4}$ approach. Depreciation of equipment used to produce geothermal energy is deductible, and the industry is classified as a small power producer under PURPA. In 1986, the depreciation allowance was changed from accelerated cost recovery system [ACRS] to modified accelerated cost recovery system [MACRS]. The rapid recovery by depreciation of costs is important to the capital intensive geothermal industry. The change from ACRS (150 percent declining balance), to MACRS (200 percent declining balance) both switching to straight line after five years, increased the importance of depreciation deductions in the early years of the project. Depreciation using MACRS is considered an important tax benefit for the industry.

\subsection{Intangible Drilling Costs}

Deductions for intangible drilling costs that can be expensed as incurred, rather than capitalized, have been important to the operations of the geothermal industry. The intangible drilling cost has no salvage value but is incident to, and necessary for, the drilling and preparation of wells for the production of geothermal hot water or steam. Intangible costs include fuel, labor,

\footnotetext{
1991 us Master Tax Guide, $\$ 1240$ Conmerce Clearinghouse
} 
repairs, site preparation, well drilling supplies, and derrick, tank, and pipeline construction. Not included are tangible assets with a salvage value such as tools, pipe, and well casings.

Intangible drilling costs can either be expensed or charged to capital. In expending, intangible drilling costs are deducted as a loss from the project's gross income in the first taxable year when such costs are incurred. If not expensed, these costs are charged to capital and cannot be deducted as a loss. These capitalized intangible costs are recovered by either depreciation (for physical property including fuel, repairs for installation and construction of wells, derricks and other physical structures) or depletion (for non-physical property such as site clearing, roads, geological work, and well drilling).

\subsection{Federal Income Taxes}

The federal corporate income tax rate is graduated from 15 to 34 percent, with a flat rate above $\$ 335,000$. This rate is applied to net operating income less federal and state deductions and depreciation. It is assumed that geothermal facilities used the 34 percent flat rate. For federal tax computations, it is assumed that the modified accelerated cost recovery system (MACRS) is used. For depreciation, geothermal plants are 5 year property, combustion and heat transfer turbines are 15 year property and steam facilities are 20 year property.

\subsection{Alternative Minimum Tax}

In order to ensure that all taxpayers pay a minimum level of tax and reduce abuses of some tax shelters, Congress enacted the Alternative Minimum Tax [AMT] in 1987. In computing the AMT, the geothermal energy tax credit is not considered, and depreciation of geothermal property is calculated over a longer time period. Net income from geothermal resources is considered a preference item, similar to drilling costs for oil and gas production, and, therefore, subject to the AMT.

Most geothermal projects are capital intensive and developers tend to be diversified with projects in several sectors, with an interest in tax credits, the effects of the AMT can be important. Since many investors in geothermal facilities are potentially subject to the AMT, this could have a strong impact by reducing the available financing for new facilities, thus requiring higher retums in order to attract investors. In relation to capital costs in general, geothermal project pro formas are not extremely sensitive to annual taxes, and the AMT does not significantly affect the project returns. In addition, project financing is based on a worst case scenario, including the full effects 
of AMT. Since AMT is project and developer specific, general statements regarding the potential effect on the geothermal industry as a whole are not appropriate.

\subsection{FINANCIAL ANALYSIS}

A general financial analysis of a representative $50 \mathrm{MW}$ binary geothermal plant was performed to determine the sensitivity to various combinations of one-time Energy Tax Credits, and production-related credits. The results indicate that geothermal projects, since they are highly capital-intensive, are financially very sensitive to tax credits and exclusions, turnkey construction costs and the utility power sales agreement rates.

The basecase analysis involved development of a viable project using a power sales agreement (PSA) rate sufficient to support a reasonable rate of return. Viability was defined as required at least a 20 percent project internal rate of retum (IRR) for a 15-year, 80 percent debt/equity long term loan. The required PSA rate is 8.48 cents/kWh (in 1996 dollars) or 9.13 cents/kWh (15 year levelized rate at 12 percent). Very few utility companies are currently forecasting avoided costs in this range for 1996, in regions where geothermal plants could be located. This rate assumes the availability of both the full tax credit and exclusion for state property taxes.

The sensitivity of this "viable basecase" project to PSA (Power Sales Agreement), EPC (Engineering, Procurement and Construction) costs, and O\&M (Operating and Maintenance) costs is shown in the following table and depicted on Figure 2. A variance of \pm 5 percent independently for PSA, EPC and O\&M was used in determining the sensitivity of the project's internal rate of return to each of these factors, with and without the energy tax credit. 


\section{TYPICAL GEOTHERMAL BINARY PLANT SENSITIVITY ANALYSIS}

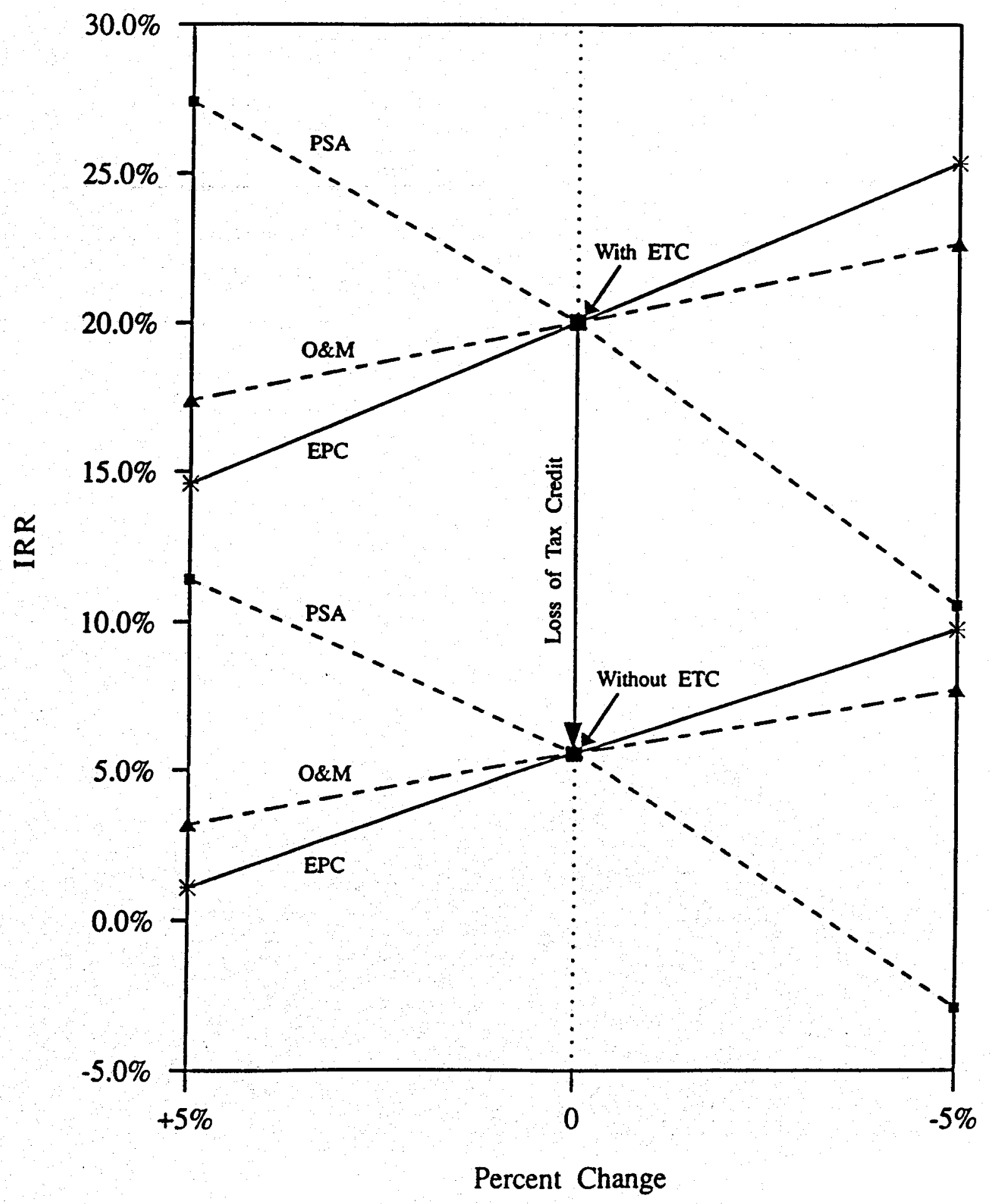

Figure 2: Typical Geothermal Binary Plant (Sensitivity Analysis) 


\begin{tabular}{|c|c|c|c|c|c|c|}
\hline & \multicolumn{3}{|c|}{ IRR (INTERNAL RATE OF RETURN) PERCENT } \\
\hline \multirow{2}{*}{ VARIANCE } & \multicolumn{3}{|c|}{$\begin{array}{c}\text { WITH } \\
\text { ENERG TAX CREDIT }\end{array}$} & \multicolumn{3}{c|}{ WITHOUT } \\
& ENERGY TAX CREDIT \\
\cline { 2 - 7 } & PSA & EPC & O\&M & PSA & EPC & O\&M \\
\hline$+5 \%$ & 27.4 & 14.5 & 17.2 & 11.4 & 0.7 & 3.0 \\
\hline 0 & 20.0 & 20.0 & 20.0 & 5.6 & 5.6 & 5.6 \\
\hline$-5 \%$ & 10.2 & 25.3 & 22.6 & -3.2 & 9.9 & 7.8 \\
\hline
\end{tabular}

The basecase retum of 20.0 percent IRR drops dramatically to 5.6 percent upon loss of the ETC. For comparison, a 5 percent decrease in the basecase PSA rate only reduces the project IRR from 20.0 percent to 10.2 percent and would be related to a decreased utility avoided cost, reflecting declining requirements for additional capacity, which is the primary reason why new geothermal plants are not being constructed. Similarly, a 5 percent increase in turnkey construction cost (EPC) results in a decrease of IRR from 20.0 percent to 14.5 percent including well field development risks. For projects less than $100 \mathrm{MW}$ in size, the loss of the ETC and property tax exclusions, result in IRR returns below the industry "threshold hurdle." For geothermal projects less than $75 \mathrm{MW}$, the loss of credits is even more critical.

\subsection{INDUSTRY REVIEW}

An informal discussion with some decision makers in the geothermal related industry was completed to develop an understanding of impacts of the tax issue on current and anticipated geothermal projects. Among those contacted were: cogeneration and PURPA Qualifying Facility developers, financial institutions, state energy commissions, engineers, and industry associations. Their collective comments reflect a sample of the diverse industry and of current views of the potential impact of tax incentives on development of new facilities. Among the pertinent comments were:

1) There was consensus that the tax credits were an essential catalyst in the initial financing in the 1980 s of a relatively new technology like geothermal, which did not have a proven performance track record. The tax credits allowed non-recourse financing through investors who 
would accept the additional risk inherent in a new technology. Some oil related companies, who developed many of the initial geothermal projects, sometimes obtained outside financing and considered the tax credit an important part of the financial package.

2) Investors in renewable technology considered the investment tax credit [ITC] and the energy tax credit [ETC] as a unique window of opportunity for geothermal projects. Now, geothermal is considered a more mature and established technology with a verifiable performance record, allowing the industry to qualify for conventional project financing. However, developers of geothermal projects, like any cogeneration project, continue to require adequate, sustainable, positive cash flows due to the initial capital intensive nature and variable operating or maintenance costs for these projects.

In general, geothermal developers have been more diverse in corporate structure than wind, solar, or other renewable technology developers. Their broad operations and substantial income from other sources may permit them to utilize a significantly larger portion of the tax credits to shelter income than other renewable developers. However, the many instances of forced recapture of tax credits from renewable energy projects in the early 1980s, due to non-performance or delays in construction, point to the risk involved in depending on tax credit revenue as an essential part of project financing.

3) Although the geothermal industry appears to support the continuation of the energy tax credits, the perception is that the impact on initiating new projects cannot be defined. This is because a project must be financially viable without relying on tax credits in order to obtain financing in the current marketplace.

4) A concern was expressed over the requirement for long-term planning for each new energy facility. It takes from one to two years to develop a geothermal power project from concept to commercial operation. Recent additional requirements for siting and environmental approval can further lengthen the development period prior to starting construction. Therefore, to be effective, the tax credit period must exceed the anticipated development and construction period for a new facility. Long-term capital intensive projects, including geothermal facilities, would require a two to four year minimum development and construction time period.

5) The new energy reality, particularly in the western states with geothermal resources, is that additional electric capacity may not be needed at the minimum PSA rate viable for 
geothermally produced power. As demand increases, utilities are mandated to select the lowest priced fuel supply power source, which is currently natural gas. Some industry representatives indicated that a specific geothermal or renewable energy tax incentive would help this capital intensive technology compete more effectively with fossil fuel plants. But, according to other industry developers, the current lack of perceived requirements for new capacity is the major factor in the decline of new geothermal plant construction, not reduced tax credits.

6) The financial experts indicated that viable cogeneration and geothermal projects must provide a positive cash flow before the applicable tax credits are considered. Concern was expressed about projects, driven by tax credits, that attract investors interested in short-term leveraged profits, but not necessarily in the long-term equity and operation of the facility. In the past, limited partnership syndications produced tax initiated ventures, many of which are no longer operational.

7) The effect of the energy tax credit in California has been very important to solar thermal projects, in particular to the industry leader LUZ, which has developed 354MW of solar power through 1991. The LUZ company's financial situation deteriorated rapidly because utility payments for avoided energy costs and related capacity payments dropped at the same time that environmental siting restrictions, labor costs, and other expenses were increasing. As the net project cash flows for operations decreased, the combination of federal and state ETC and the state property tax exemption became very important to LUZ's survival, along with the ACRS and MACRS depreciation. By 1990, LUZ was a technical success, producing 95 percent of the world's solar thermal electricity in nine plants at a cost of $\$ 1.25$ billion. However, the fluctuating legislative support for the energy tax credits along with PURPA size limitations, and a two month delay in licensing approval, compounded a weak financial situation, and LUZ was forced to reorganize under Chapter 9 and 11 of the Bankruptcy Code in November 1991. As shown in the financial analysis, (Appendix A), capital intensive projects such as geothermal and solar are very sensitive to power sales rates and capital costs. Even minor delays or financing problems can cause potentially fatal, major, amplified perturbations to a capital-intensive project. 


\subsection{STATE FINANCIAL INCENTIVES}

Numerous states have financial initiatives designed to support renewable energy developments. The only current California state credit is for solar electric and solar thermal electric (10 percent ETC), and it is due to expire on December 31, 1993. There is no tax credit for geothermal. In Nevada, the value of energy derived from conversion of a qualified renewable energy system, including solar, wind, geothermal, water power and solid wastes, is exempted from property taxes. In Utah, the commercial tax credits for renewables ended at the end of 1990, but a bill in the legislature would extend them through 1995 for certified solar projects. No other state has a direct geothermal tax incentive.

Of importance in Califomia is the effect of state and local property taxes. For example, capital-intensive solar thermal projects like LUZ, will have paid, over 30 years, four times the state and local property taxes of a comparably powered combined cycle cogeneration facility. Geothermal taxes are similar. The California Energy Commission (CEC) analyzed the tax impact if renewables received various combinations of property tax exemption, federal ETC, state ETC, and MACRS depreciation. CEC found that with all four benefits included, renewable project tax payments to the state dropped almost to the level currently paid by fossil fuel plants, on the basis of cumulative taxes paid. Therefore, more tax benefits could be extended to renewable power projects including geothermal, to correct the imbalance in tax payments. Similar property tax exemptions for renewable energy sites could be granted to the geothermal industry.

\subsection{INTERNA TIONAL FINANCIAL INCENTIVES}

The recent interest in global warming and other environmental concerns has prompted many industrial countries to encourage the development of benign renewable resources, including geothermal energy. This has been the case outside the U.S. in Japan, Italy, New Zealand, Iceland, and other countries with potential geothermal resources. In the past, there has been strong financial support for R\&D of prototype facilities and demonstration plants supported by foreign govemments. The new programs are designed to develop geothermal facilities as active and competitive power plants, and provide "a wide range" of financial support including the use of tax credits, direct and indirect subsidies to purchasers of power from geothermal facilities, and special tariff rates. 


\subsection{Italy}

Geothermal resources in Italy have been developed by ENEL, the state electric power company, and financing is indirectly controlled by the Government of Italy. In 1990, one new geothermal unit was initiated (15 MW) and ENEL has developed plans for 35 new geothermal plants to produce over $1000 \mathrm{MW}$ by the year 2000 , to add to the existing $521 \mathrm{MW}$ of installed capacity. In January 1991, the government initiated renewable energy grants, designed to support up to 40 percent of the investment cost for all new geothermal plants by ENEL or other developers.

\subsection{Japan}

Geothermal and hydropower are the only energy resources indigenous to Japan. With the policy and security concerns inherent in importing all Japan's fossil fuel requirements, renewable energy is being strongly supported. To stimulate the increased use of geothermal resources, various incentives were established by the Japanese Government in the "Energy 2000" plan. The current geothermal capacity of $275 \mathrm{MW}$ is expected to quadruple to over $1000 \mathrm{MW}$ by the year 2000 , driven by a combination of fiscal and monetary incentive programs. Low interest loans for utilities and power facilities investing in geothermal energy are available from the Japan Development Bank. The current rate is 5.9 percent for financing up to 40 percent of the total construction cost, or 5.8 percent for financing up to 50 percent of the total development costs of any geothermal project. Additional special geothermal related loans, at special low rates, are available from the New Energy Foundation. Tax incentives for investment in the development, construction and operation of geothermal plants are available on national and local levels, particularly in remote regions with strong geothermal potential. As a further incentive to utilize geothermal facilities and expand their market competitiveness, plants used for government requirements can be subsidized to a level competitive with fossil fuel plants. Since financing is a critical part of each project, it is anticipated that these incentives will be strong motivations for accelerating geothermal operations. 


\section{APPENDIX A - DISCUSSION OF THE BASECASE ANALYSIS}

A general financial analysis was performed to determine the quantitative effects of various combinations of one-time Energy Tax Credit (ETC), state property tax exclusions, and productionrelated ETC. The pro forma analysis used is an industry-standard pro forma for fossil-fuel cogeneration modified to incorporate geothermal energy. The same pro-forma has been used extensively to analyze both a geothermal project and a solar project for industry independent power developers. The results indicate that geothermal projects, since they are much more capitalintensive, are very financially sensitive to tax credits and exclusions.

The representative "avoided unit" in the basecase analysis represents a net $50 \mathrm{MW}$ binary geothermal plant with the following system characteristics:

$50 \mathrm{MW}$ net to utility

Average well depth of 8,000 feet

Reservoir saturated temperature of $179^{\circ} \mathrm{C}$

Total dissolved solids of $6 \%$

Net brine effectiveness of 6.2 watt hours per pound

Producer average flow of 510,000 pounds per hour

Development time of 2.0 years

Capacity factor of $81 \%$ (assumed $88 \%$ utility dispatch and $92 \%$ availability)

Construction time of 2.5 yrs

\section{CAPITAL REOUIREMENTS}

Turnkey System Price ${ }^{5}$ (at Time of Performance)

MM (1992\$) $\$ 1,835 / \mathrm{Net} \mathrm{kW}$

Contingency

Equipment (spares, tools, mobile equipment)

Intertie

Discovery \& Well Field Development

Venture Management Fees

Pre-Operating Costs

0.50

Working Capital

100\% Equity

Financing Costs/Fees

Debt Reserve (6 months interest only)

Interest During Construction (30 month construction)

\footnotetext{
Turnkey price includes escalation and site specifics.
} 
$\$ 3,233 / \mathrm{Net} \mathrm{kW}$

OPERATION EXPENSES

FIXED O\&M:

Labor

Admin \& TLM

Land Lease

Insurance

Total

Well Field R\&M
(MM 1996\$)

1.48

0.35

0.09

0.98

3.97

6.87

(MM 1996\$)

1.18

0.65

$\underline{0.03}$

1.86

Total

Consumables and Water

Repair
Consum
Utilities

FORECASTS

Basecase Power Purchase Contract (Required Rates for viable project) (1996\$)

Energy:

Var O\&M

Capacity:

Fixed O\&M:

(cents/kWh)

(cents/kWh)

0.0

(\$/kW-Mo)

0.500

(\$/kW-Mo)

35.75

TOTAL EQUTVALENT RATE

15 yr Levelized (@12\%)

(cents/kWh)

11.46

25 yr Levelized (@12\%)

(cents/kWh)

8.481

(cents/kWh)

9.128

9.455

EINANCIAL ASSUMPTIONS

Year Term

Long-Term Interest Rate

15.0

Years of Deferred Principal

Short-Term Interest Rate

Debt Reserve: months of interest only

Performance Bond LOC (\% of Face Value)

$10.0 \%$

1.0

$9.0 \%$

6.0

$1.0 \%$

\section{KEY ASSUMPTIONS}

Commercial Operation Date

General Escalation (GNP/CPI)

Utilization availability

PSA Contract Term (Years)
1996

$4.5 \%$

$80 \%$

30 


\section{DISCUSSION OF RESULTS}

Figures A-1, and A-2 display typical revenue and expense streams for the basecase 50MW binary geothermal project with one-time Energy Tax Credit (ETC) and State Property Tax Exclusion (PTx Excl). The sensitivity analysis in Figure A-3 indicates the extreme sensitivity of this geothermal project pro forma to both EPC Turnkey construction cost and PSA (Power Sales Agreement). In less capital intensive cogeneration technologies such as natural gas combined cycle plants, while these variables are always the most sensitive, the resulting effects on project returns are much less sensitive.

\begin{tabular}{|c|c|c|c|c|c|c|}
\hline \multicolumn{7}{|c|}{ IRR (INTERNAL RATE OF RETURN) PERCENT } \\
\hline \multirow[t]{2}{*}{ VARIANCE } & \multicolumn{3}{|c|}{$\begin{array}{c}\text { WTTH } \\
\text { ENERGY TAX CREDIT } \\
\end{array}$} & \multicolumn{3}{|c|}{$\begin{array}{c}\text { WITHOUT } \\
\text { ENERGY TAX CREDIT } \\
\end{array}$} \\
\hline & PSA & EPC & $\mathbf{O} \& \mathbf{M}$ & PSA & EPC & $\mathbf{O} \& \mathbf{M}$ \\
\hline$+5 \%$ & 27.4 & 14.5 & 17.2 & 11.4 & 0.7 & 3.0 \\
\hline 0 & 20.0 & 20.0 & 20.0 & 5.6 & 5.6 & 5.6 \\
\hline$-5 \%$ & 10.2 & 25.3 & 22.6 & -3.2 & 9.9 & 7.8 \\
\hline
\end{tabular}

As shown in Table A-1 the 20.0 percent IRR basecase pro forma includes the proposed ETC. Removing the ETC drops the returns dramatically to 5.6 percent, a non-viable project according to industry threshold requirements.

A 5 percent increase in EPC construction cost for the basecase results in a decrease in the 15 year IRR from 20.0 percent to 14.5 percent. Likewise, a 5 percent decrease in the basecase PSA rate results in a decrease in the IRR from 20.0 percent to 10.2 percent. Thus, the needs of a utility for additional capacity, reflected in part by the avoided cost rates it is allowed to pay for additional capacity, is also one of the most sensitive variables in the project pro forma. This quantitative representation reinforces industry's comments that geothermal pro forma sensitivity to the need for new capacity has been more of a detriment to geothermal development than the project sensitivity to an ETC.

Further compounding the EPC result is the longer construction period for geothermal projects (e.g.,30 months compared to a normal 18 months for a gas cogeneration plant). Any delay in construction results in larger construction interest penalties and results in additional EPC budget overruns. This effect would be in addition to that just shown for an EPC overrun.

By far the most risky development cost prior to construction is the discovery and development of the well field. This expense is relatively fixed regardless of the plant size. Since, in general, some of this cost is not offset by credits, any increases in this development cost are disastrous to smaller plants whose cash flows cannot sustain large overruns. 
The sensitivity analysis above for EPC and PSA variables reflects the effects of the loss of the one-time 10 percent ETC (e.g., equivalent to an increase in EPC tumkey cost) and the proposed production-linked ETC (e.g., equivalent to a $2.5 \mathrm{cts} / \mathrm{kWh}$ loss in the basecase PSA rate). Compared with these, the effects of changes in annual O\&M are quite minimal, as also occurs in other cogeneration technology pro forma.

The effects of a one-time Energy Tax Credit on IRR are shown in Figures A-4 and A-5, compared with a production-linked ETC at $2.5 \mathrm{cts} / \mathrm{kWh}$ for 10 years. Exclusion from state property taxes on the geothermal facility are also shown. For this basecase analysis we have "developed" a viable project (e.g., developers require at least a 20 percent project IRR for a $15 \mathrm{yr}, 80$ percent debt/equity leverage long-term loan), and then calculated the PSA rate required to support the project. This PSA rate tumed out to be $8.481 \mathrm{cts} / \mathrm{kWh}$ (in $1996 \$$ ) or $9.128 \mathrm{cts} / \mathrm{kWh}$ (15 yr levelized rate at 12 percent discount factor). The pro forma used is a standard utilized at several of the largest independent power cogeneration developers and has been validated and used to evaluate natural gas, coal, wood, solar and geothermal power projects. Very few utilities are forecasting avoided costs in this range in 1996 in the regions where geothermal plants might be constructed. However, this is the minimum acceptable "basecase" scenario rate, even with the ETC. The required rate to obtain a viable project will be even higher without the ETC.

In Figure A-4, The IRR at 80 percent leverage the production-linked ETC (10yr ETC) combined with a state property tax exclusion (PTx Excl) yields substantially higher returns, especially for smaller projects below $75 \mathrm{MW}$. The one-time ETC ("ETC") combined with PTx Excl gave similar results above $100 \mathrm{MW}$ to the production-linked case, but drops off significantly below that size. This is primarily because the well field capital expense in smaller projects can exceed the power block capital expense and is not granted a compensating credit. The next two lower return lines are due to reducing the PTx Excl credit or the one-time ETC, respectively, while retaining the other. The loss of the PTX Excl is clearly shown as less significant than the loss of the ETC. The final bottom curve indicates the project returns without ETC or PTx Excl credits and is not profitable at any size. Similar results are obtained by analyzing the impact of IRR on ETC factors at $85 \%$ leverage, as indicated in figure A-S.

Several results become obvious for this typical basecase scenario. Loss of either the ETC and PTx Ex credits for projects in size, less than $100 \mathrm{MW}$, results in retums below the industry "threshold hurdle." The IRR is not viable with the loss of both credits. For projects less than 75 MW, the loss of credits is more critical. IRR using production-linked credits tend to be less sensitive to plant size than those for the ETC. 


\section{TYPICAL GEOTHERMAL BINARY PLANT \\ Revenues Vs. Expenses}

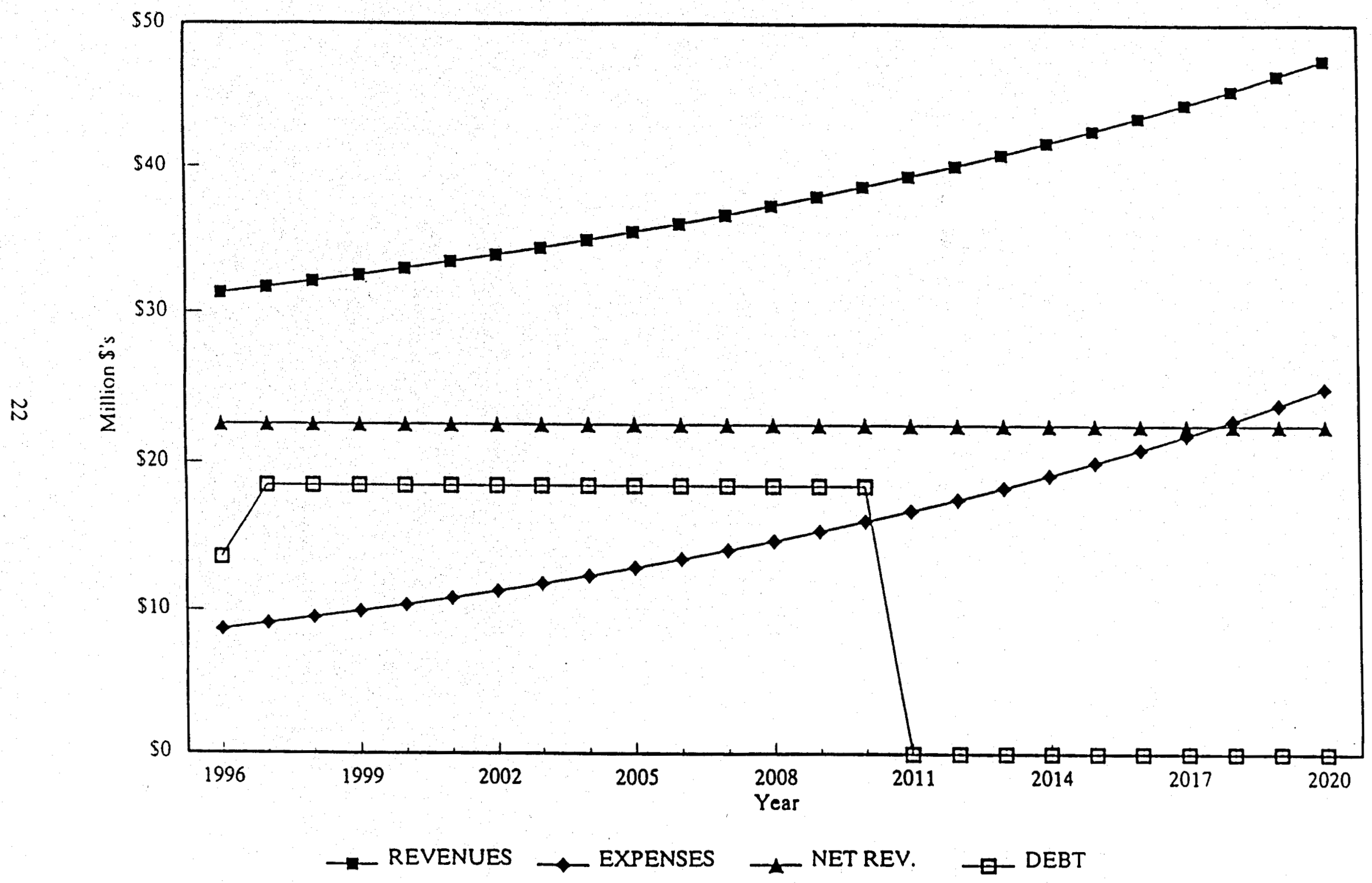

Figure A-1: Typical Geothermal Binary Plant (Revenues vs. Expenses) 


\section{TYPICAL GEOTHERMAL BINARY PLANT}

Cumulative Revenues vs. Expenses

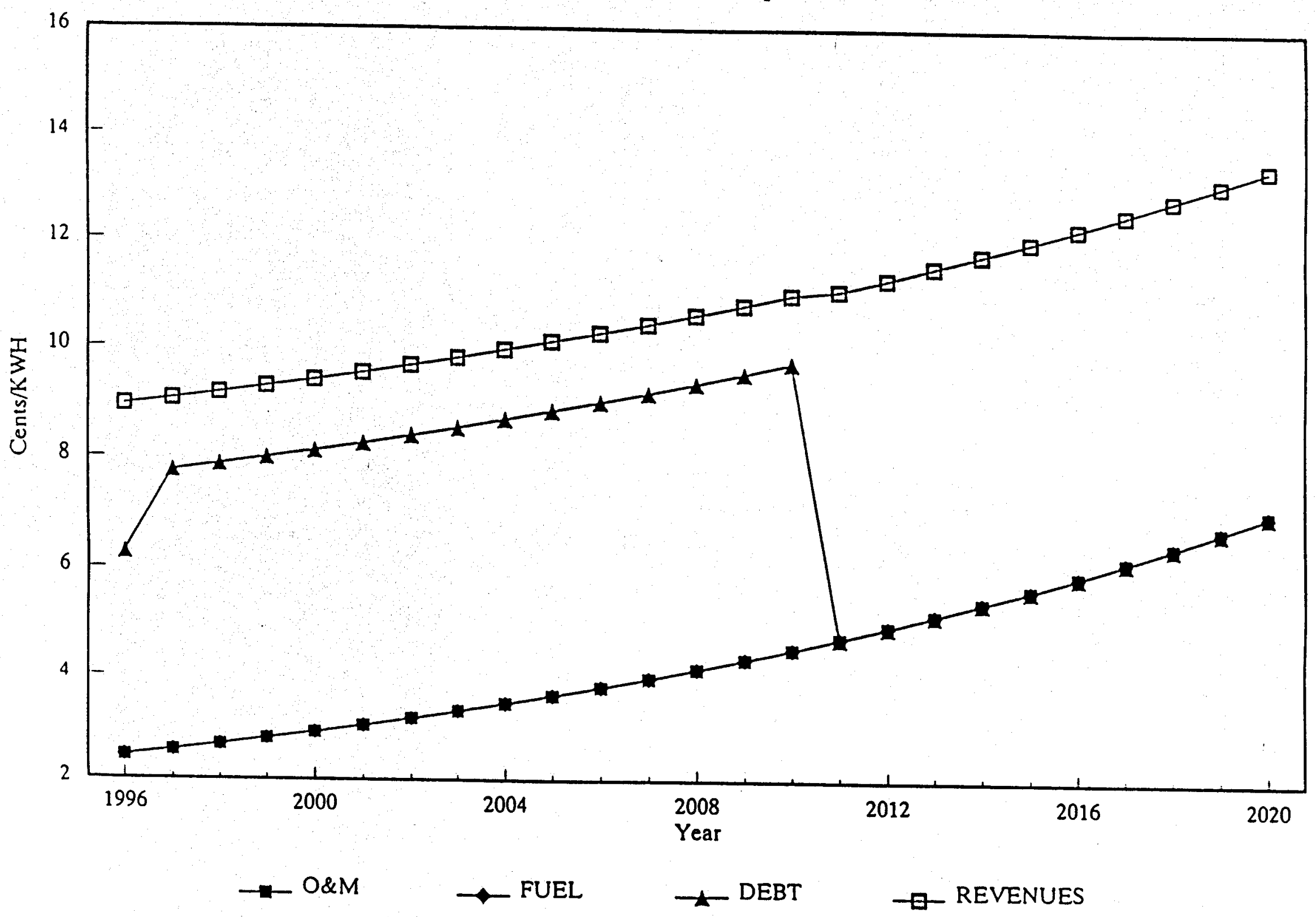

Figure A-2: Typical Geothermal Binary Plant (Cumulative Revenues vs. Expenses) 


\section{TYPICAL GEOTHERMAL BINARY PLANT}

SENSITIVITY ANALYSIS

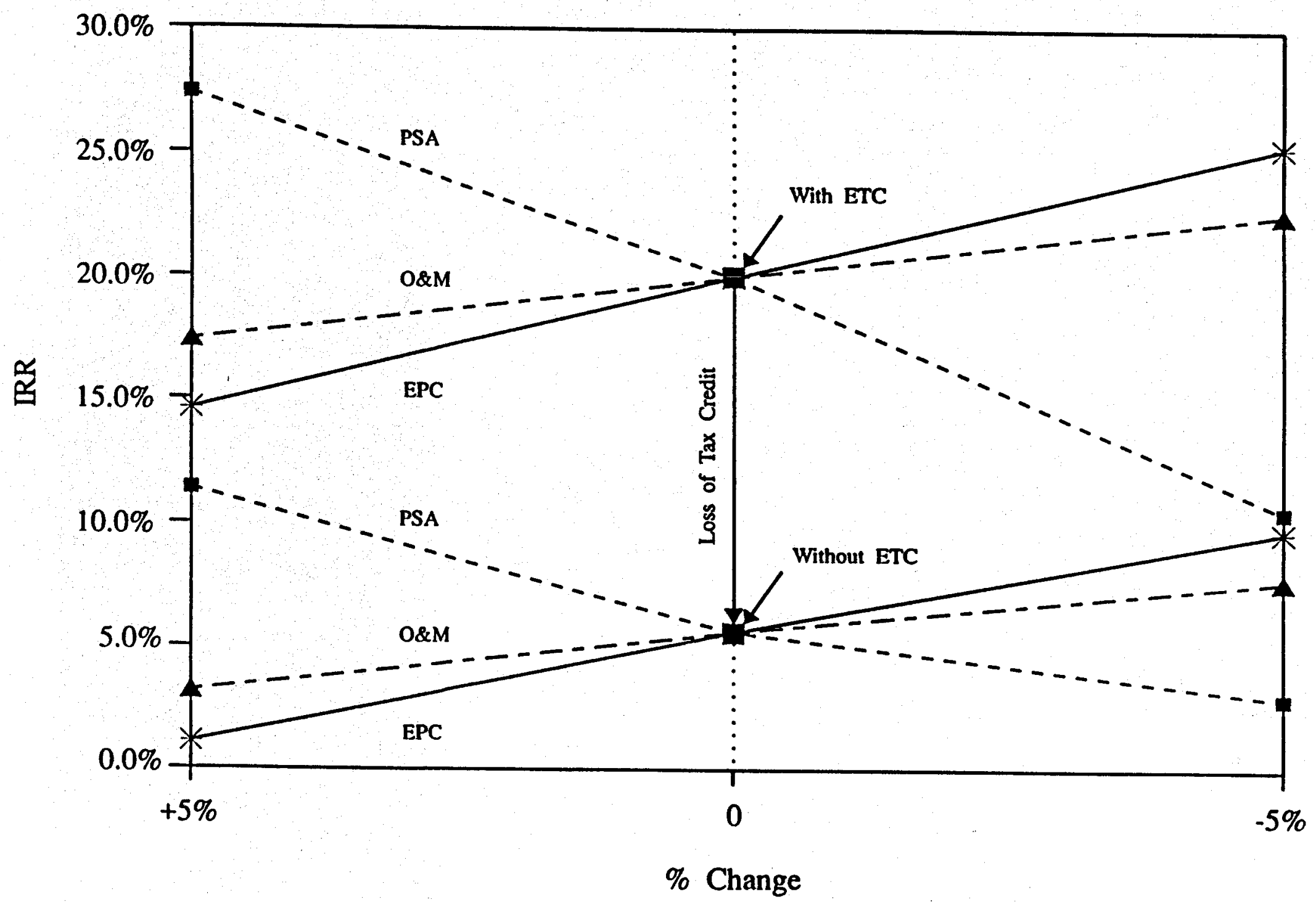

Figure A-3: Typical Geothermal Binary Plant (Sensitivity Analysis) 
IRR AT 80\% LEVERAGE FOR GEOTHERMAL BINARY PLANT

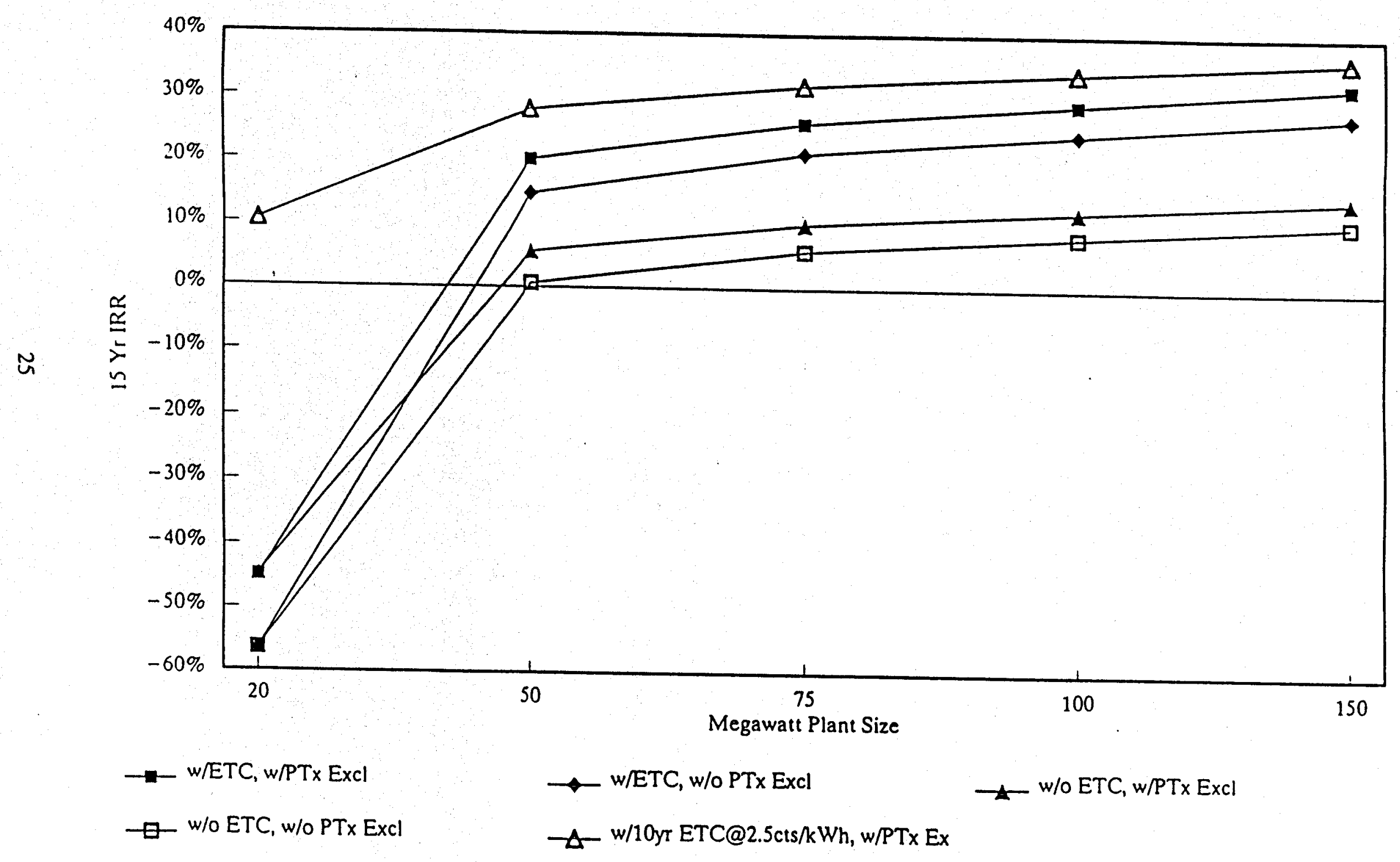

Figure A-4: Geothermal Binary Plant (80\% Leverage) 


\section{IRR AT 85\% LEVERAGE FOR \\ GEOTHERMAL BINARY PLANT}

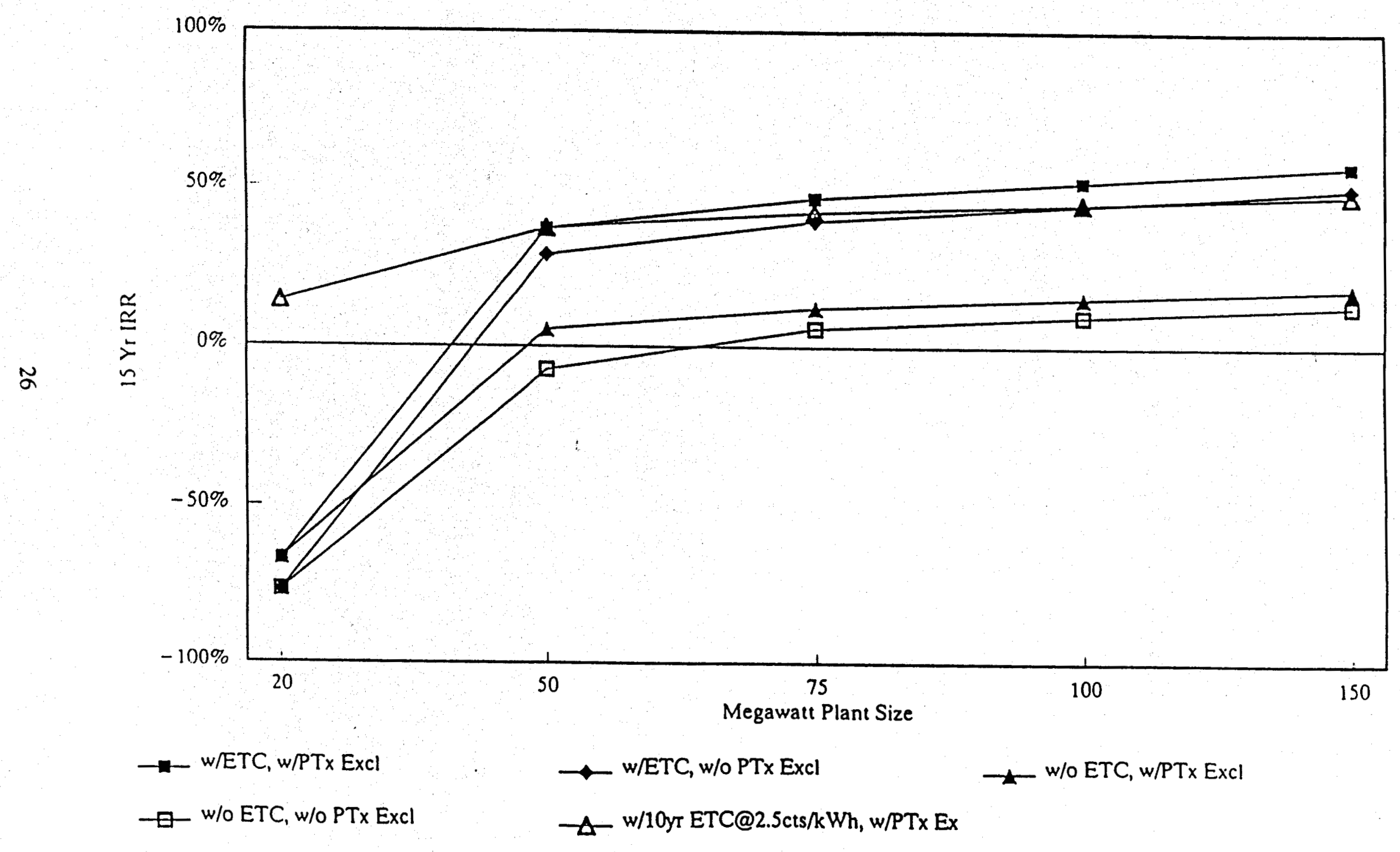

Figure A-5: Geothermal Binary Plant (85\% Leverage) 


\section{APPENDIX B - GLOSSARY OF ECONOMIC TERMS}

ACRS:

Annual Value:

Benefit-Cost Analysis:

Benefit-Cost Ratio:

Constant Dollars:

Current Dollars:

Discount Rate:

Discounted Payback

Period:

Discounting:

Economic Efficiency:

Economic Life:

Future Value (Worth):

Incentive:
Depreciation schedule using Accelerated Cost Recovery System.

Benefits or costs occurring in uniform amounts annually, or the uniform annual equivalents of past, present, or future benefits.

A means of evaluating alternative projects or investments by comparing the discounted value of total expected benefits with the discounted value of total expected costs for each alternative.

Benefits expressed as a ratio to cost, where both are discounted to a present or annual value; the ratio must be greater than one for an investment to be economically efficient.

Values expressed in terms of the general purchasing power of the dollar in the base year. Constant dollars do not reflect price inflation.

Values expressed in terms of actual prices of each year. Current dollars reflect price inflation.

The rate of interest reflecting the time value of money that is used to convert benefits and costs occurring at different times to equivalent values at a common time.

The time required for the cumulative net benefits derived from an investment to pay back the investment cost, considering the time value of money.

A technique for converting cash flows that occur over time to equivalent amounts at a common point in time.

Maximizing net benefits or minimizing costs for a given level of benefits.

The period of time over which an investment is considered to be the least-cost alternative for meeting a particular objective.

The value of a present dollar amount at some point in the future, considering the time value of money.

A positive inducement to encourage a particular type of behavior or action. 
Inflation:

Internal Rate of Return (IRR):

Grants:

Investment Cost:

Life Cycle:

Life-Cycle Cost:

MACRS:

Marginal Analysis:

Monetary Benefits:

Net Benefits:

Nonmonetary Benefits:

Operation and Maintenance Costs:

Payback:

Present Value (Worth):
A rise in the general price level resulting from a decline in the purchasing power of the dollar.

The interest rate for which the total discounted benefits from an investment equal its total discounted costs.

Cash payments for the purpose of encouraging a particular practice or the use of a good or service by reducing its net cost to the owner or user.

The sum of the planning, design, and construction costs necessary to provide a finished project ready for use.

The period of time between the starting point and cutoff date of analysis, over which the costs and benefits of a certain alternative are incurred.

The total of all relevant costs associated with an activity or project during the time it is analyzed. For buildings, life-cycle costs include all costs of owning, operating, and maintaining a building over its period of analysis, including its energy costs.

Depreciation schedule using Modified Accelerated System Cost Recovery Systems.

Evaluating incremental changes in costs and benefits resulting from incremental changes in an investment.

Benefits assigned a dollar value.

The difference between benefits and costs, evaluated in present or annual value dollars.

Benefits to which it is difficult to assign dollar values.

The costs associated with the normal operation and maintenance of a system, often accumulated on a recurring basis.

(See Discounted and Undiscounted Payback Period)

Past and future cash flows expressed in time-equivalent amounts as of the present time, adjusted for inflation and the time value of money. 
Probability Analysis:

A technique, also called expected value analysis, used to evaluate the dollar value of an event whose expected chance of occurrence can be predicted.

Pro-Forma:

A standard financial analytical procedure developing the impact of revenue and expense flows during the project life.

Salvage Value:

The net sum to be realized from disposal for an asset, net of disposal costs, at the time of its replacement, resale, or at the end of the study period.

Sensitivity Analysis: Testing the outcome of an evaluation by altering the values of key factors about which there is uncertainty.

Time Horizon

(Study Period):

A period of economic analysis over which time the costs and benefits of an investment are calculated.

Undiscounted Payback The length of time necessary for the cumulative benefits or Period (Simple Payback): savings resulting from an investment to recover the original cost of the investment, not considering the time value of money.

Useful Life:

The period over which an investment is considered to have value.

Source: Derived from NBS publication 544, U.S. Dept. of Commerce. 